\title{
Correction: a method to estimate cell cycle time and growth fraction using bromodeoxyuridine-flow cytometry data from a single sample
}

Rimantas Eidukevicius1, Dainius Characiejus*2, Ramunas Janavicius, Nijole Kazlauskaite ${ }^{2}$, Vita Pasukoniene ${ }^{2}$, Mykolas Mauricas ${ }^{3}$ and Willem Den Otter $^{4}$

Address: ${ }^{1}$ Faculty of Mathematics and Informatics, Vilnius University, Naugarduko 24, 03225 Vilnius, Lithuania, ${ }^{2}$ Institute of Oncology, Vilnius University, Santariškių 1, 08660 Vilnius, Lithuania, ${ }^{3}$ Institute of Immunology, Vilnius University, Moletų pl. 29, 08409 Vilnius, Lithuania and ${ }^{4}$ Department of Pathobiology, Utrecht University, P.O.Box 80158, 3508 TD Utrecht, The Netherlands

Email: Rimantas Eidukevicius - rimantas.eidukevicius@sc.vu.lt; Dainius Characiejus* - dainius@banga.lt;

Ramunas Janavicius - ramujana@gmail.com; Nijole Kazlauskaite - nile@loc.lt; Vita Pasukoniene - vita@loc.lt;

Mykolas Mauricas - mauricas@imi.lt; Willem Den Otter - w.denotter@vet.uu.nl

* Corresponding author

Published: II July 2006

BMC Cancer 2006, 6:184 doi:10.1 186/147|-2407-6-184

This article is available from: http://www.biomedcentral.com/147I-2407/6/184

(C) 2006 Eidukevicius et al; licensee BioMed Central Ltd.

This is an Open Access article distributed under the terms of the Creative Commons Attribution License (http://creativecommons.org/licenses/by/2.0), which permits unrestricted use, distribution, and reproduction in any medium, provided the original work is properly cited.
Received: 10 July 2006

Accepted: II July 2006

In our article in BMC Cancer [1] we modelled our graph for the passage of bromodeoxyuridine-labelled cells through the cell cycle presented in Figure 1 on the figure published by Johansson et al. [2]. We regret that we failed to quote this article and we are grateful to its authors and the editors for bringing this matter to our attention.

\section{References}

I. Eidukevicius R, Characiejus D, Janavicius R, Kazlauskaite N, Pasukoniene $V$, Mauricas $M$, Den Otter W: A method to estimate cell cycle time and growth fraction using bromodeoxyuridineflow cytometry data from a single sample. BMC Cancer 2005, 5:122.

2. Johansson MC, Baldetorp B, Bendahl PO, Johansson R, Oredsson SM: An improved mathematical method to estimate DNA synthesis time of bromodeoxyuridine-labelled cells, using FCMderived data. Cell Prolif 1994, 27:475-488.

\section{Pre-publication history}

The pre-publication history for this paper can be accessed here:

http://www.biomedcentral.com/1471-2407/6/184/pre

pub 